保健物理, 11, 289 302（1976)

資料

\title{
保健物理分野の文献調査法（その 2)
}

\section{2 次資料の利用と文献調査の実際}

（1976年10月30日受理）

Literature Search in the Field of Health Physics (II)

Daisaku SHICHI ${ }^{* 1}$

\section{VI 抄録・索引誌の利用}

ある研究テーマに関する文献調査を行ならにあたっ て，見過すことができない大切なことは，いくらその研 究者に適合した文献が集められたからといって，その原 文献が入手できなかったり，著しくその入手が遅れるよ らでは，文献調査を行なえなかったのと同じであるとい 5点にある。そこで前回（その1）では，自機関所蔵の 資料を除けば，まず第 1 亿，保健物理分野の文献を集約 的に収集している原研図書館の所藏資料に注目していた だくと有効であろうと確信し，同図書館の利用の仕方と その利用のトゥールである「資料情報」その他について 紹介した。

本来,「文献調查法」といらことであれば，まず最初 に抄録・索引誌が取りあげられるのが普通であるのに， 本文ではあえてその順序を逆にしてみた。それは各機関

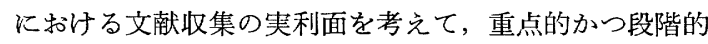
(計画的)に情報資料を整備できるように配虑しょうと した現われである。

そこで, 原研図書館所藏資料を対象とする 2 次資料の つぎに整備すべきものは，文献調査の網ら的信頼性を期 待するならば，やはり抄録誌 Nuclear Science Abstracts (NSA) であろう。

現在までに NSA 以上の原子力分野の文献蓄積が汪か

*1 日本原子力研究所技術情報部; 茨城県那珂郡東海村 (广 319-11)

Div. of Technical Information, Japan Atomic

Energy Research Institute; Tokai-mura, Nakagun, Ibaraki-ken.
にないので，ある種の文献調査を行なら場合，だれしも まずこれを利用してみようと考劣るのは正しい。きちん と製本してある NSA を前にして，実際にいろいろと調 査してみると, 原子力分野の文献が完全に網らされてい ると思われるほど，よく文献が集まっている。したがっ て, 保健物理分野の文献調查を定常的に行なら可能性の ある機関で，NSA をまだ完備していない機関には速や かに整備されるようお勧めする。前回にるのべたよう に，NSA は1976年 6 月で廃刊となり，INIS Atomindex に引きつがれたが，NSA とその索引の過去の蓄積はま だ当分の間有用である。

\section{Nuclear Science Abstracts}

(1) Nuclear Science Abstracts, Vol. 1 (1948) Vol. 33 (1976) : 年 24 回。U.S. ERDA 発行 (略称: NSA)。

原研所蔵: Vol. 1 (1948) Vol. 33 (1976)

NSA は創刊以来1974年までで, 84 万 8651 件に達する 原子力科学技術分野の文献を収録する世界最大の抄録誌 である。収録文献総数のうち，雑誌論文その他が 59 万 4224 件 $(70 \%)$, レポートが 25 万 4427 件 (30\%) となっ ている。保健物理分野の文献の収録状沉は, NSA の分 類項目 Life Sciences と Environmental and Earth Sciences に収録された1974年 1 年間の文献数によれば, 前者が 6429 件 $(9.7 \%)$, 後者が 2306 件 (3.5\%) で, 合計 8735 件 $(13.2 \%)$ である。この比率は, NSA 創 刊以来について累計してみても, そら大きく変動するこ とはあるまいと思われる。すちろん, 保健物理分野が必 要とする文献は, NSA の他の分類項目のなかにも分散 されているので，上記の比率は目安としてあげたに過ぎ 


\section{ENVIRONMENTAL AND EARTH SCIENCES}

Minerals and Ores

Radioactive Effluents

Radioactivity Monitoring and Transport

Atmosphere

Soil

Water

Ecosystems and Food Cycles

Radiometric Techniques

Site Surveys

Thermal Effluents

Chemical Effluents

LIF E SCIENCES

Radiation Effects on Biochemicals

Radiation Effects on Cells

Radiation Effects on Microorganisms

Radiation Effects on Plants

Radiation Effects on Animals

Man

Vertebrates

Invertebrates

Radionuclide Effects (Internal Source)

Man

Animals

Nuclide Kinetics and Toxicology

Man

Animals

Plants

Microorganisms

New Tracer Techniques

\section{NUCLEAR MATERIALS AND WASTE}

\section{MANAGEMENT}

Accountability and Safeguards

Disposal and Storage

Handling Equipment and Procedures

Transportation

\section{第 1 図 NSA の分類大項目の一部}

3041 (BNWL-1843). STUDIES ON MANAGEMENT OF SELECTED WASTES. Quarterly Progress Report, April-June 1974. Schneider, K. J. (Battelle Pacific Northwest Labs., Richland Wash. (USA)). Jul 1974. Contract AT(45-1)-1830. 29p. Dep. NTIS (USA)).

Progress is reported in the areas of decontamination and densiProgress is reported in the areas of decontamination and densi-
fication of chop-leach cladding residues, waste treatment and handling processes, and tritium separation and fixation. (LK)

\section{第 2 図 NSA の文献記述（レポートの場合）}

ない。

NSA は創刊当初より 1 年間あたり 24 号発行され， 毎年その収録件数を増加させてきた。1957年の収録件数 1万4000件にたいして，1974年が6万6000件であるから， 17年間で 4.7 倍増である。一般に, 科学技術分野全体の 文献の倍増期は15年とされているので，原子力分野のこ の倍増率は異常に急速である。

NSA の各号は，本文として分類項目別に文献を収録 し，各号末に団体著者，個人著者，主題，レポート番号

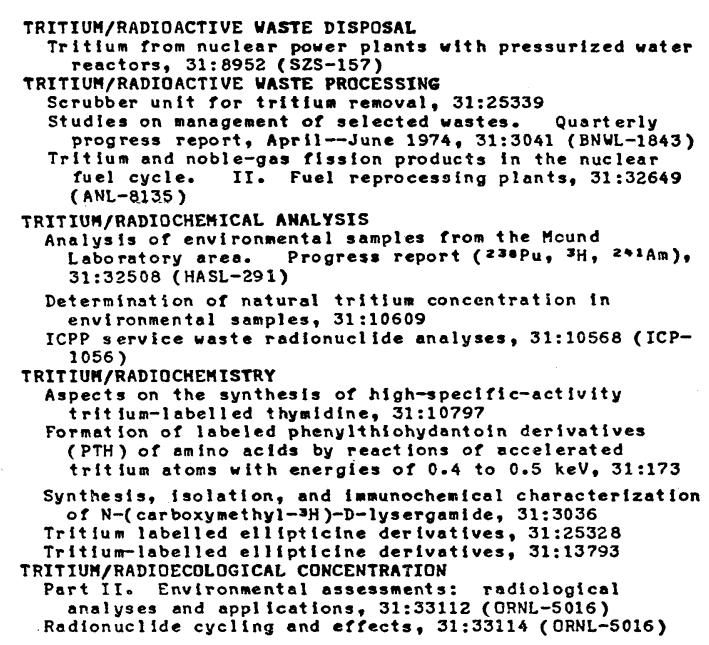

第 3 図 NSA の主題索引の一部 (tritium の項)

の各索引をそなえている。NSA の分類項目のらち，保 健物理分野に直接関係する項目は第 1 図のと括りであ る。また，各分類項目のなかに収録された文献の記述 は，第 2 図のと特りである。利用者は，それぞれ関連す る項目のなかを定期的にサーベイすることも，また索引 によって特定の文献を見出すこともできる。

索引は各号末の注か，1970年をでは大体 5 年間ごとの 累積索引が，1971年からは 1 卷あたりの半年間索引が作 られている。な拈, 過去に拈いては, 四半期索引も作成 されていた時期もあって, 利用上きわめて便利であっ た。これらの索引によって，過去にさかのぼって文献調 査を行ならことができる。主題索引の編成方法は何度か 変更があったが, 最近ではVol. 28 (1973) 以降, Atomindex の方式に合せて，索引語/サブテーマのもとに 文献が列挙されることとなった（第 3 図）。

たと觉ば，「放射性廃棄物中のトリチウムの挙動」と いらテーマで文献調查をしようとする場合，索引によっ て tritium を引き（第 3 図にトリチウムの項目の一部を 揭載した), さらに tritium/radioactive waste processing といらサブテーマが見出される。このテーマのもと に, 文献 Studies on Management of Selected Waste 31 : 3041 (BNWL-1843) が標題, 抄録番号, レポート 番号の順に記述されている。

この記述だけでは, 調査項目であるトリチウムの挙動 がぞれだけのっているのかわからない。そこで，まず抄 録によって確認しようと思えば，抄録番号 (31: 3041) によってただちに抄録本文にたどることができる。ある いは，抄録番号のあとのレポート番号 (BNWL-1843) に 


$\begin{array}{lll}\text { BNWL- } & & \\ 253 & 31: 20179 & \text { Dep. NTIS, } \$ 7.75 \\ 309 & 31: 17023 & \text { Dep. NTIS, } \$ 6.75 \\ 394 & 31: 20180 & \text { Dep. NTIS, } \$ 10.50 \\ 787 & 31: 19515 & \text { Dep. NTIS, } \$ 6.50 \\ 934 & 31: 20181 & \text { Dep. NTIS, } \$ 6.75 \\ 1835 & 31: 29294 & \text { Dep. NTIS, } \$ 7.60 \\ 1836 & 31: 11252 & \text { Dep. NTIS, } \$ 4.00 \\ 1837 & 31: 5396 & \text { Dep. NTIS, } \$ 7.50 \\ 1841 & 31: 3040 & \text { Dep. NTIS, } \$ 5.45 \\ 1842 & 31: 13901 & \text { Dep. NTIS, } \$ 4.00 \\ 1842 & 31: 5173 & \text { Dep. NTIS, } \$ 5.45 \\ 1843 & 31: 3041 & \text { Dep. NTIS, } \$ 4.00 \\ 1844 & 31: 10819 & \text { Dep. NTIS, } \$ 4.00 \\ 1845-1 & 31: 16717 & \text { Dep. NTIS, } \$ 5.45 \\ 1845-2 & 31: 19826 & \text { Dep. NTIS, } \$ 5.45 \\ 1845-3 & 31: 16718 & \text { Dep. NTIS, } \$ 4.00 \\ 1845-4 & 31: 19827 & \text { Dep. NTIS, } \$ 4.50 \\ 1845-5 & 31: 22863 & \text { Dep. NTIS, } \$ 4.00 \\ 1847 & 31: 6817 & \text { Dep. NTIS, } \$ 4.00 \\ 1848 & 31: 5263 & \text { Dep. NTIS, } \$ 4.00 \\ 1850(P t .1) & 31: 846 & \text { Dep. NTIS, } \$ 13.60 \\ 1852 & 31: 12143 & \text { Dep. NTIS, } \$ 5.45\end{array}$

第 4 図 NSA のレポート番号索引（BNWLの項の 一部)

よって，いきなりレポートの現物にあたることができる (なお，レポート番号の記載がなければ，雑誌論文その 他の資料であることを意味する)。

自機関のレポート・ファイルに BNWL-1843 がない 場合には, 前回（その1）でのべたように原子力弘済会 を通じて原研図書館に申込めば入手できる。その場合， レポート番号索引（第 4 図）を参照すれば，大よその入 手の目安をつ计ることができる。レポート番号索引は， レポート記号の A B C順, そのなかは数字の番号順とな っている。これにより BNWL-1843 が見出されると， そのあとの availavility (入手法) の欄に, Dep. NTIS, $\$ 4.00$ といら記載がある。ここで Dep. とは，米国国内 の ERDA レポートの deposit library (寄託図書館)を 意味する。一方，原研図書館にたいして ERDA は米国 内寄託図書館へ送付しているのとほとんど同じセットを 交換送付しているので，availavility の欄に Dep. の記 載があれば，原研図書館が所蔵していることを意味す る。

また，自機関で米国から直接 ERDA レポートを購入 することも，もちろんできる。この場合， availability の闌に NTIS，\$4.00 とあれば， NTIS (National Technical Information Services) から 4.00 ドルで購 入できることを意味するので，そのことを明示して一般 の洋畫取扱い書店に発注すればよい。ERDA レポート は全セットでも, 指定されている主題分野別でも, NTIS から購入できる。ただし，入手するまでに最低 3 カ月は かかる。上記のように個々に発注するとなると, 入手に もっと期間がかかるかもしれない。

団体著者索引と個人著者索引も有用である。たとえ ば，「高レベル放射性廃棄物の管理」について文献調査

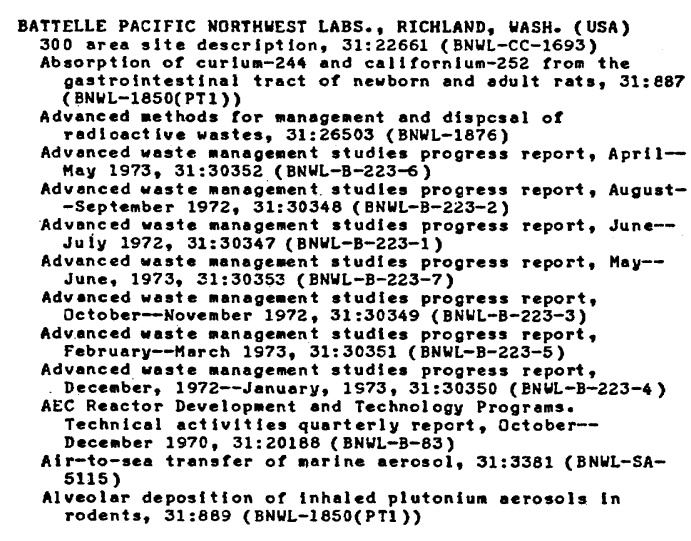

第 5 図 NSA の団体著者索引 (BNWL の一部分)

をする場合，米国では Battle Pacific Northwest Laboratories (BNWL) に颃いて，その研究执よび管理 実務を主としてやっていることを知っていれば，団体著 者索引で BNWL の数年分の研究概要を簡単に把握する ことができる(第 5 図)。

もっとも BNWL では, 高レベル廃棄物だけを研究し ているわけではないので，かなりの数にのぼる文献のな かから選択しなければならないが，このよらな比較的広 いテーマならば, 主題索引によるよりも幅広くひろえる ことがある。さらに過去にさかのぼって丹念に精查すれ ば, BNWL では注添何年ごろから高レベル廃棄物の研 究を開始し, 現在どういう状況にあるのかもらかがい知 ることができる。

もちろん, 高レベル廃棄物の研究を行なっているのは BNWL だけではない。しかし，BNWL が高レベル廃 衰物については米国内で重点的に研究を行なっている機 関だとすれば，BNWL だけの文献を精査することによ って，その文献の引用文献などから， ある程度同研究の 現状と水準を手早く知ることができる。このような団体 著者索引の使い力は, 研究テーマについての重点的文献 調査といえるであろう。研究テーマだからといって, 主 題索引だけを使らのが索引の使い方ではない。

個人著者索引も，上記と同様の使い方ができる。文献 調査がかなり進んだ段階になると，自分と同じ研究をし ていて，しかもほとんど同じ方向性をもっている著者に ぶつかることがある。このような場合，その著者には最 も関心があるので，NSA の最近号が入荷すると，まず 個人著者索引でその著者の有無を確かめてから，その他 の記事を見る習慣が身につくようになる。しかし，この ような個人著者索引の使い方は, 実際にはごく特殊な事 
例で，普通はつぎにのべる文献（資料）探索に用いられ る。

個人著者索引によって求むる文献を捜し出そうとする 場合，普通にはつぎのような 2 例が考えられる。第 1 は，自分に関心のある著者が最近または過去にどのよう な論文を畫いているのかを知りたい場合である。これは 最も簡単で, 索引が完備されていれば，直らにたどるこ とができる。

個人著者索引の使い方の第 2 は, ある文献の著者と題 名はわかっているが，それがどらいら資料にのっている 論文なのかわからない場合である。このよらな場合，個 人著者索引によってその著者にあたり，その著者のもと の文献記述のなかから求むる題名（項目）が見出されれ ば，そのあとに記載されてある抄録番号によって抄録本 文にあたれば，求むる資料名（雑誌名，レポート番号そ の他）が得られる。

NSA とその索引の過去の蓄積は，このよらにきわめ て有用であり，今後とも実用として使われるので，その 完備を重ねて扣勧めする次第である。

NSA とその索引の入手価格は, NSA 各号の第 1 ペー ジに記載されている分を転載する。

NSA 本文 Vol. 1 26 (1948 1972)，16 ミリ・35 ミ リのマイクロフィルムで, 730 ドル

NSA 主題・著者累積索引

Vol. 1〜4（1948〜1950), 30 ドル

Vol. 5〜10 (1951〜1956), 5.25 ドル

NSA 主題・個人著者・団体著者累積索引

Vol. 11〜 15 (1957 1961), 35.75 ドル

Vol. 16 20 (1962 1966), 62.25 ドル

Vol. 21〜25 (1967〜 1971), 195 ドル

NSA 年間索引

Vol. 26 (1972)，37， 75 ドル

NSA 半年間（1 巻あたり）索引

Vol. 27 (1973), 16.90 ドル

Vol. 28 (1973), 18.55 ドル

Vol. 29 (1974), 20.10 ドル

Vol. 30 (1974), 27.35 ドル

NSA レポート番号累積索引

Vol. 1 15, 4 ドル

Vol. 16 20, 5.55 ドル

Vol. 21 28, 9.35 ドル

NSA はさきにものべたように，Vol．23（1976年6月） で廃刊となり, INIS Atomindex に引きつがれた。な 拈，米国エネルギー開発庁は，NSA を廃刊させると同 時に，新たに ERDA Energy Research Abstracts を
1976年 1 月より発行しはじめた。

\section{INIS Atomindex}

(2) INIS Atomindex, Vol. 1 (1970) : IAEA 発行 (略称 Atomindex)。

原研所蔵：Vol. 1 (1970) -

NSA の後継誌として, Atomindex は Vol. 7 (1976) より抄録誌となった。しかし，Atomindex は単なる NSA の後継誌ではなく，その主体は電算機処理にもと づく情報検索にあって，Atomindex はその情報検索の 副産物である。しかも，INISの人間-機械システムにと って重要な副産物であるところに Atomindex の意義が ある。

Atomindex は, 細かい点では NSA と異なるが, 利 用者にとっては NSA と同じだとみてよい。Atomindex 各号の分類項目は第 6 図のと叔りで，NSA のそれとは 少し異なる。本文の文献の記述は第 7 図のとおりで, NSA よりは厳密になっている。資料の記述部分も厳密 で，主要外国語には英文を併記している。そのため，か えって原資料の標題をひと眼で確認するのは，一般の利 用者にはなかなか困難である。

索引部分も NSA のそれと大体同じで, 主題索引は第 8 図, 団体著者索引は第 9 図, 個人著者索引は第 10 図, レポート番号は第 11 図のとおりである。NSA の各索引 と比べてみれば明らかなように，Atomindex のどの索 引にも記述のあとにレポート番号（その文献がレポート である場合）の記載がない。このように, 細かい点では 少し不便な箇所もある。しかし，新たに設けられた会議 索引 (Conference Index) はきわめて有用である（第 12 図)。

INIS が他の情報システムと比較してすぐれている点 は, INIS は情報（磁気テープとその出力である Atomindex）を提供するばかりでなく，収録した文献資料の らち一般の市販ルートでは入手できない資料（非市販資 料，つまり全資料の約 $30 \%$ にあたる原子カレポート) を提供する措置がとられている点である。

INIS の情報サービスについてはべつにのべているの で1)，ここではこれ以上ふれない。INIS の母体である IAEA (国際原子力機関) は, 周知のように政府加盟の 国際機関であるから，原研に扣けるINIS の仕事は，国 からの指令による事業である。したがって, INIS の情 報機械検索は，原研所内にとどまらず，可及的速やかに 広く国に還元しなければならない情報サービスである (Atomindex や非市販資料は書店を通じて購入できる が，機峨検索サービスは原研技術情報部からしか得られ ない)。このため原研技術情報部では, 昭和 52 年度以降 
A00-PHYSICAL SCIENCES

A10-GENERAL PHYSICS

A11-Theoretical Physics

A12-Atomic and Molecular Physics

A13-Solid State and Fluid Physics

A14-Plasma Physics and Thermonuclear Reactions

A15-Astrophysics and Cosmology, Cosmic Radiation

A16-Direct Energy Conversion

A17-Low-Temperature Physics

A20-HIGH ENERGY PHYSICS

A21-Elementary Particles (Theory)

A22-Elementary Particles (Experimental)

A30-NEUTRON AND NUCLEAR PHYSICS

A31-Neutron Physics

A32-Radiation Physics

A33-Nuclear Theory

A34-Nuclear Properties and Reactions

B00-CHEMISTRY, MATERIALS AND EARTH

SCIENCES

B10-CHEMISTRY

B11-Chemical and Isotopic Analysis

B12-Inorganic, Organic and Physical

Chemistry

B13-Radiochemistry and Nuclear Chemistry

B14-Radiation Chemisty

B15-Corrosion

B16-Fuel Processing and Reprocessing

B20-MATERIALS

B21-Metals and Alloys (Production and

Fabrication)

B22-Metals and Alloys (Physical Properties and Structure)

B23-Ceramics and Cermets

B24-Other Materials

B25-Radiation Effects on Physical Properties of Materials

B30-EARTH SCIENCES

B31-Land

B32-Water

B33-At mosphere

C00-LIFE SCIENCES

C10-ALL EFFECTS AND VARIOUS

ASPECTS OF EXTERNAL RADIATION

IN BIOLOGY

C11-Effects of External Radiation on

Biochemicals and Cell and Tissue Cultures

C12-Effects of External Radiation on

Microorganisms

C13-Effects of External Radiation on Plants

C14-Effects of External Radiation on Animals

C15-Effects of External Radiation on Man

C20-RADIONUCLIDE EFFECTS AND

KINETICS

C21-Toxicology, Tissue Distribution,

Metabolism, and Removal of Radionuclides C22-Radionuclide Ecology

C30-TRACER STUDIES IN LIFE SCIENCES

C31-Novel Tracer Techniques

C40-APPLIED LIFE SCIENCES
C41-Plant Cultivation and Breeding

C42-Pest and Disease Control

C45-Other Applications of Radiations and

Radioisotopes in the Life Sciences

C50-HEALTH, SAFETY AND ENVIRONMENT

C51-Radiation Hazards

C52-Safety Evaluations and Environmental

Aspects of Nuclear Installations

C53-Radiation Protection Standards

C54-Radiation Protection Procedures

C55-Personnel Dosimetry and Monitoring

D00-ISOTOPES, ISOTOPE AND RADIATION

APPLICATIONS

D10-ISOTOPES AND RADIATION SOURCES

D11-Production of Enriched Uranium

D12-Production of Heavy Water

D13-Other Isotope Production and Enrichment

D14-Radiation Sources

D15-Radiation Source Metrology

D20-ISOTOPE AND RADIATION

APPLICATIONS

D21-Power Production

D22-Industrial Applications, Radiometric

D23-Industrial Applications, Radiation

Processing

D24-Tracer Techniques

E00-ENGINEERING AND TECHNOLOGY

E10-ENGINEERING

E11-Thermodynamics and Fluid Flow

E12-Cryogenics

E13-Structure and Equipment

E14-Nuclear Explosions

E15-Facilities for Handling of Radioactive

Materials

E16-Accelerators

E17-Materials Testing

E20-NUCLEAR REACTORS (GENERAL)

E21-Reactor Theory and Calculation

E22-Reactor Components and Accessories

E23-Reactor Fuels

E24-Reactor Control Systems

E30-REACTOR TYPES

E31-Power Reactors, Non-Breeding, Light-

Water Moderated, Boiling Water Cooled

E32-Power Reactors, Non-Breeding, Light-

Water Moderated, Non-Boiling Water Cooled

E33-Power Reactors, Non-Breeding,

Graphite-Moderated

E34-Power Reactors, Non-Breeding,

Otherwise Moderated or Unmoderated

E35-Power Reactors, Breeding

E36-Research and Test Reactors, Including

Experimental and Training Reactors

E37-Production Reactors and Irradiation Reactors

E38-Mobile, Propulsion, Transportable and

Package Reactors

E40-INSTRUMENTATION

E41-Particle and Radiation Detection and

Measuring Instruments and Methods

E42-Other Nuclear Instrumentation and 
Methods of Measurement

E43-Radiation Effects on Instruments,

Components or Electronic Devices

E50-WASTE MANAGEMENT

E51-Waste Treatment

E52-Waste Disposal

F00-OTHER ASPECTS OF NUCLEAR ENERGY

F10-ECONOMICS

F11-Nuclear Power Economics

F12-Reactor Fuel Economics

F20-NUCLEAR LAW

F22-Nuclear Installations

F23-Radiation Health
F24-Transport and Storage of Radioactive Materials

F30-NUCLEAR DOCUMENTATION

F31-Data Handling

F40-SAFEGUARDS AND INSPECTION

F42-Non-Technical Aspects

F50-MATHEMATICAL METHODS AND

COMPUTER CODES

F51-Nuclear Computation and Simulation

F60-MISCELLANEOUS

F61-General Relevant Documents

F62-Progress Reports

第 6 図 INIS Atomindex の分類項目

\section{PHYSICAL SCIENCES}

\section{GENERAL PHYSICS}

\section{A11 - Theoretical Physics}

See also 262299, 263772

261577 Abdulloev, Kh.O.; Bogolubsky, I.L.; Makhankov, V.G. (Joint Inst. for Nuclear Research, Dubna (USSR)). One more example of inelastic soliton interaction. Phys. Lett., A. (3 May 1976). v. 56(6) p. $427-428$.

Inelastic interaction of solitons has been obtained via computer within the framework of the 'improved' Korteweg-de Vries type equation, usub(t) $+(\operatorname{usup}(n)) \operatorname{sub}(\mathbf{x})+\operatorname{usub}(\mathbf{x x x})=0, n=2,3$, which is important from the point of view of the common Fermi-Pasta-Ulam problem. (Auth.).

SOLITONS: korteweg-de vries equation.

第 7 図 Atomindex の文献記述（雑誌論文の場合）

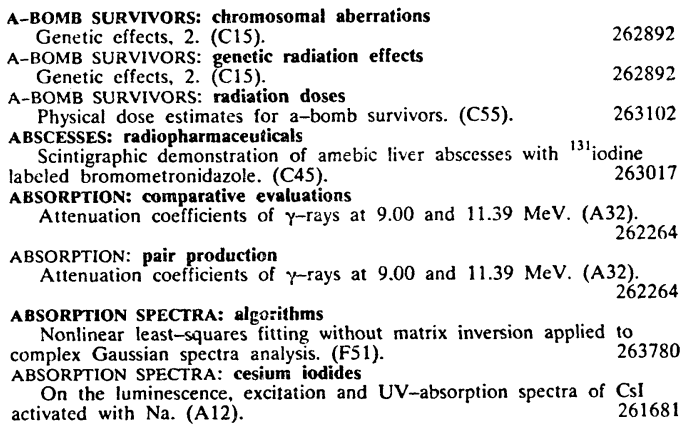

\section{第 8 図 Atomindex の主題索引（Aの最初の部分）}

には国内の利用者にたいして定期的な情報機械検索サ一 ビスができるよう，現在，部の総力をあげて努力してい るところである。

Atomindex と非市販資料の価格は, Atomindex によ るとつぎのとおりである。

Atomindex (with Index) 年24回発行

$$
\begin{aligned}
& \text { 船便 : } 150 \text { ドル } \\
& \text { 航空便 : } 270 \text { ドル }
\end{aligned}
$$

Atomindex 年24回発行

\section{$\mathbf{A}$}

AN Ehstonskoj SSR, Tartu. Inst. Fiziki

Adiabatic surface and emission characteristics of the impurity centres with two optical electrons. 261768

A correct value of $n-p$ mass difference. 262175

Equivalence relations between interacting Kemmer-Duffin and KleinGordon spin 0 and 1 boson fields. 261578

Essentially nonlinear lagrangians, asymptotic expansions and the uniqueness problem. 261629

Muon polarization in neutrino-induced binary processes. 262190

On the theory of energetic structure of the Wannier-Mott exciton in a dielectric medium. 261740

The Osub(1.4) type relativistically invariant equation for representation Osub(1.4) $[(2 \mathrm{n}+1) / 2,1 / 2] .261607$

Radiation tails of the scalar wave equation in a weak gravitational field. 261612

Tails of the electromagnetic and gravitational waves in a weak gravitational field. 261611

AN SSSR, Novosibirsk. Inst. Geologii i Geofiziki

Application of nuclear radiations in geophysical exploration. 262810

AN Ukrainskoj SSR, Kharkov. Fiziko-Tekhnicheskij Inst.

Nuclear science and engineering problems. 262202, 263242, 263243, $263244,263245,263246,263248,263250,263251,263252$, $263244,263245,263246,263248,263250,263251,263252$, 263254, 263255, 263256, 263257, 263258, 263259, 263260, $263261,263264,263266,263271,263275,263282,263283$, 263309, 263310, 263311, 263312, 263315, 263316, 263317, $263309,263310,263311,263312$,

Nuclear science and engineerino. problems. 263285

Nuclear science engineering problems. 263308

Plasma physics and problems of controlled thermonuclear fusion. 261918

第 9 図 Atomindex の団体著者索引（Aの最初の 部分)

\section{$\mathbf{A}$}

Aashamar, 0 .

The K-shell ionization induced by protons: projectile scattering angle and electronic relativistic effects in the SCA calculations. 261631

Abagyan, A.A. Secondary gamma radiation problems in reactor shielding. 263333

Abdel-Hamid, A. See Hoepfner, A. 262520

Abdulaev, G.B.

IR spectroscopy study on vibrational spectra of $\mathrm{CdInGaS}_{4}$ crystals. 261688

Abdulloev, Kh.O.

One more example of inelastic soliton interaction. 261577

Abe, Jiro

See Ugajin, Mitsuhiro 262737

Abramov, B.M.

Study on the $\Delta(1236)$ isobar production in the $\pi^{-}+\mathrm{d} \rightarrow \mathrm{p}+\Delta^{-}\left(\Delta^{-}-\right.$ back) from 1,03 to $1,68 \mathrm{GeV} / \mathrm{c}$. 262217

Study on the $\pi^{-}+d \rightarrow p+\pi^{-}+n$ with great momenta transfered to proton in primary momentum range $1,25-2,64 \mathrm{GeV} / \mathrm{c}$. 262218

Abramova, I.M.

See Bol'shakova, N.I. 262633

Abushady, Y.

A generalized collision probability method for thermal cell calculations. 263334

See Elmeshad, Y. 263340

第 10 図 Atomindex の個人著者索引（Aの最初の 部分) 


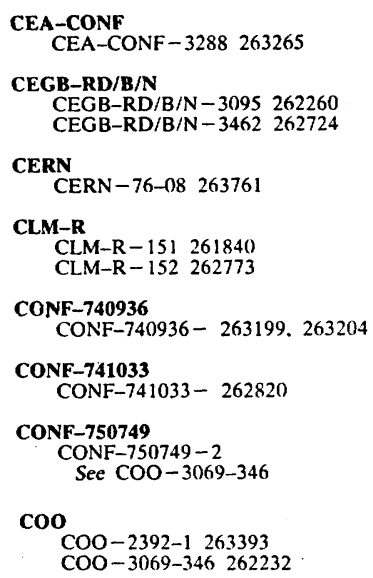

第 11 図Atomindex のレポート番号索引（Cの最 初の部分)

76 Jan 19. Mainz, F.R. Germany. Symposium on waste disposal in nuclear engineering, sponsored by the Deutsches Atomforum. 263753.

76 Jan 26. Atlanta, Georgia, United States of America (USA). 6 symposium on the sharing of computer programs and technology in nuclear medicine. 262947.

76 Feb 4. Juelich, F.R. Germany. Professional meeting: technologies for better utilization of heat in thermal power stations. 263441 . 263704 .

76 Feb 19. Hamburg F.R. Germany. German cancer congress. 262912 76 Feb 19. Muenster, F.R. Germany. Discussion meeting of the solid state chemistry section of the Gesellschaft Deutscher Chemiker. state chemistry section of the Gesellschaft Deutscher Chemiker. Physikalische Gesellschaft. 261835, 261836, 261839, 261841,
Physer. $261845,261851,261852,261855,261857,261858,261860$, $261864,261875,261884,261885,261886,261891,261894$, $261895,261897,261899,261905,261906,261907,261913$, $261916,261917,261919$.

76 Feb 24. Essen, F.R. Germany. VGB seminar 'Maintenance'. 263442 263455, 263711 .

76 Mar 4. Freiburg, F.R. Germany. Macromolecular colloquium. 262583. 76 Mar 10. Karlsruhe, F.R. Germany. Spring meeting of the technical committee nuclear physics and high-energy physics section B: particle physics of the Deutsche Physikalische Gesellschaft e.V. 262244.

第 12 図 Atomindex の会議索引（年代順配列で 1976年の部分)

船便 : 110 ドル

非市販資料（レポート）

全セット：マイクロフィッシ 1 件あたり 0.20 ドル

1 件：マイクロフィッシ 1 件あたり 0.65 ドル

\section{3. その他の抄録・索引サービス}

(3) Chemical Abstracts, Vol. 1 (1907) : Chemical Abstracts Services 発行 (略称 CA)。

原研所蔵 : Vol. 25 (1931) -

化学，化学工業およびそれに関連する分野の広範囲 な，最も著名な抄録誌なので，ここには詳述しない。購 入費は抄録誌中最も高価で，CA with Index で年間 150 万円もする。すでにCA を所蔵している機関では，すで
にCA の有用性をよく知っているし，また多少なりとす CA の解説書, 利用ガイドを集めておられることと思 う。そこで本項では，CA がいかに保健物理研究者にと って有用であるかを示し，CA 整備が必要なことを明ら かにしよう。

前回にも引用した赤石 ${ }^{2}$ による Health Physics 誌の 引用文献の集計結果によれば，1975 年 (Vol. 28, 29) 分の引用文献の上位雑誌 10 誌をとりあげてみると以下 のと拈りである。

1位: Health Physics (50\% 以上)

2位 : Radiation Research (15\% 以上)

3位: Nature（10\% 以上)

4位: Physics in Medicine and Biology (5\% 以上)

5 位: Science（5\% 以上)

6位: Analytical Chemistry (5\% 以上)

7位 : British J. of Radiology (5\% 以上)

8位: J. of Nuclear Medicine (5\% 以上)

9位 : Proc. of Soc. Exp. Biol. Med. (5\% 以上)

10位 : Int. J. of Appl. Rad. Isotopes (5\% 以上)

以上 10 タイトルの雑誌は，すべて CA の収録対象誌 に入っている。以上 Health Physics 誌に引用された雑 誌は 200 誌にのぼるが，これらの大部分は CA の収録 対象誌に入っているはずである。したがって，保健物理 研究者が少しでも系統的に文献調查をする場合，CA は 必須の調査トゥールである。

な特，CA の場合，保健物理研究者にとって CAのど の分類項目がとくに関係するかといらことはいえない。 そういったことから CA は，保健物理研究者にとって定 期的な文献調査のトゥールといらよりは，むしろ特定テ 一マの過去分調査のための重要なトゥールと見るべきで あろう。CA に恀数の生物学・医学雑誌をも収録の対 象としているので, 化学に隣接する生物学・医学の問題 ならば, Index Medicus や Biological Abstracts によ らずとも，CA でもある程度は答えることができる。

(4) Physics Abstracts, Vol. 1 (1898) : Inspec 発行 (略称 PA)。

原研所蔵 : Vol. 49 (1946) -

PA は，物理学分野の代表的な抄録誌である。PA に ついても，上記 CA の項でのべたことと同じことがいえ る。Health Physics 誌 1975 年の引用文献の集計結果に よると, 雑誌論文の引用頻度順位第 13 位に, 代表的な 物理学分野の原著雑誌である Physical Review が入っ ていることを明記して抗こう。なお，PA 本文の分類項 目のなかで保健物理に直接関係する大項目としては, 9.700 項の Biophysics and Medical Physics がある。 
(5) Government Reports Announcements, Vol.1 (1946) : U.S. Department of Commerce, National Technical Information 発行 (略称 GRA)。

原研所蔵：Vol. 27 (1957) -

科学技術分野にたいして米国政府が出資して各研究機 関に研究開発を行なわせた結果である米国政府レポー ト,すなわち, $\mathrm{AD}, \mathrm{PB}, \mathrm{NASA}, \mathrm{ERDA}$ 等レポートの 抄録誌である。原子力レポートについてはNSA, Atomindex と重複するが, 保健物理研究者は, 原子カレポ 一ト以外のレポートにも多分に関心があるはずなので, GRA はやはり重要な文献調査のトゥールである。保健 物理研究者が利用した全資料の約 $50 \%$ がレポートであ ることを想起すれば，納得できるであろう。GRA の分 類項目で保健物理に直接関係する項目としては, Field4： Atmospheric Sciences, Field 6 : Biological and Medical Sciences, Field 18: Nuclear Science and Technology がある。

上述したような大規模な抄録・索引誌のほかに, 主題 範囲を専門的にしぼったものも多数発行されている。こ れらのららから, 保健物理分野に最も関係し, 最近発行 されはじめた抄録誌を 1 件だけとりあげ，解説してみよ ら。

(6) Applied Health Physics Abstracts and Notes, Vol. 1 (1975)：(年 4 回)。Nuclear Technology Pub. 発行 (略称 AHPA)。

原研所蔵：Vol. 2 (1976)-

AHPA の分類項目と分類コードは，第 13 図のと扬り である。分類項目には，大項目が用いられている。本文 の文献の記述は，第14図のと特りである。標題の右に抄 録番号と，その下に分類コード番号が枠内に入れられて いる。これによって, 関連する主題を知ることができ る。また, 主題索引はすべてこの分類コード番号の累積 として作成されている。巻末には, 主題索引, 著者索引 (第 1 著者のみ) の泳か Conference Report（主要会議 の一部または全部の論支の抄録）とBook Reviews（新 刊紹介）の欄を設けている。現在のところ, AHPA は ページ数も少なく (Vol. 2, No. 1 で 112 ページ), 比 較的小規模であるが, 保健物理の中心的課題にアプロー チするには非常に便利である。

これらの抄録・索引誌のほかに, 比較的小規模で主題 範囲もかなりせばをるが，雑誌のなかに「抄録欄」，「文 献目録」などとして，定期的に掲載される抄録・索引サ 一ビスがある（本誌「保健物理」の同欄も Health Physics 誌に限定していて小規模ながらなかなか有用であ る)。これらのなかにも実によくまとまっていて，実用
として使えるものが少なからずある。以上のよらな抄録 ・索引誌およびサービスを収録したガイドブック（3 次 資料）として，下記のものがある。

(7) A Guide to the World's Abstracting and Indexing Services in Science and Technology, National Federation of Science Abstracting and Indexing Services, 1963, $183 \mathrm{p}$.

発行は1963年で古いが，現在にいたるもこれだけ抄録 ・索引サービスについて系統的にまた科学技術分野全 般にわたって網らしている資料は見当らない。このガイ ドブックには，まず巻頭に UDC 項目別に抄録・索引サ 一ビスが列挙されている。保健物理に直接関係する「保 健・予防医学 (UDC：613/614)」の項だけで, 28 件の タイトルが列挙されている。本文はタイトルのA B C順 配列で，1855件収録されている。記述は書誌的事項のほ か, 簡単な解説がついている。巻末には国別索引のほ か, 主題索引もそなえている。

本資料の1963年以降の空白は, 結局雑誌カタログや学 協会誌の紹介欄や広告を精查していく以外にはない。日 本で発行されたガイドブックとしては下記のものがあ り，実用に供されている。

（8） 2 次資料の解説：科学技術文献抄録・索引誌ガイ ドブック, ドキュメンテーション懇談会編, 日本ドクメ ンテーション協会発行, 1969, $109 \mathrm{p}$.

これらのガイドブックを出発点として，自機関にどれ だけ 2 次資料を整備すれば最適であろらか?

いまのところ，その最適值，つまり，原著雑誌対抄録 誌の収集の最適比率はまだでていない。もしかしたら， その最適值は存在せず，それぞれの機関の情報サービス 部局（図書館）の最高責任者による経営政策上の判断で きまるものかもしれない。しかし，その判断を決めさせ るのが，その図書館を利用する研究者の判断と要望なの であるから, 研究者側も上述した 2 次資料をよく知って いなければならない。

\section{VII 単行の文献集の利用}

上述した継続刊行の 2 次資料のほかに，単独で発行さ れる主題別文献集がある。単行であるから自ずから継続 刊行とは, その発行の由来, 目的等に执いて当然異な る。単行の文献集は，大規模な抄録誌と比較すると，必 然的により狭いテーマに指向する。また，抄録誌は網ら するために網らする傾向があるが，単行の文献集は研究 目的のために網らする。

そこで文献調查のさい，その研究者にとって適切な文 献集を見いだすことができれば，大半の文献探索の作業 
KEYWORDS AND CODING

\section{GROUP}

1.1 Man

1.2 Children

1. 3 Foetus

1.4 Standard Man

1.5 Patients

1.6 Phantom

1.7 Population

1.8 Others/General

PARTICLES AND PHOTONS

2.1 Neutrons

$2.2 \quad r$ Rays

2.3 X-Rays

$2.4 \quad \beta$ Particles/Electrons

2.5 Protons

2.6 $\alpha$ Particles

2.7 Auger Electrons

2.8 Others

2.9 Cosmic Rays

ORGANS AND TISSUES

$\begin{array}{ll}3.0 & \text { General } \\ 3.1 & \text { Abdomen }\end{array}$

3. 2 Blood

3. 3 Bone

3.4 Gonads

3.5 GI Tract

3.6 Kidney

3.7 Liver

3.8 Lungs

3.9 Lymphatic System

3.10 Skin

3.11 Spleen

3.12 Thyroid

3.13 Tissue

3.14 Whole Body

3.15 Wounds

3.16 Others

3.17 Eyes

DOSIMETRY

4. 0 General

4.1 LET

4.2 Quality Factors

4.3 RBE

4.4 Absorbed Dose

4.5 Exposure and Kerma

4.6 Dose Equivalent

4.7 MPC, MPL, DWL, ERL, MPAI etc.

4. 8 Non Uniform Effects, Particles

4.9 Dose Response

4.10 Units

4.11 Mathematical Models

4.12 Radiobiology

4.13 Personnel Dosimetry

4.14 Internal Contamination

4.15 Shielding

4.16 Dose Distribution

4.17 Dose Measurement

4.18 Dose Commitment

4.19 Others
4.20 Energy Response

4.21 Criticality

TRANSPORT OF RADIOACTIVE MATERIAL

5.1 Regulations

5. 2 Container Design

5.3 Container Testing

5.4 Safety Assessment

5.5 Operating Experience

5.6 Accidents

5.7 Others

MEASUREMENT TECHNIQUES

6. 0 General

6.1 Film Badge

6.2 Thermoluminescence

6. 3 Glass Dosimeters

6. 4 Neutron Dosimeters

6.5 Criticality Dosimeters

6. 6 Detectors

6.7 Survey Instruments

6. 8 Whole Body Monitors

6.9 Hand and Foot Monitors

6.10 Calibration, Standards etc.

6.11 Airborne Radioactivity etc.

6.12 Surface Contamination

6.13 Others

6.14 Scintillation Techniques

6.15 Use of Computers

6.16 Spectrometry

6.17 Solid State

6.18 Ion Chambers

RADIATION EFFECTS

7.0 General

7.1 Cells

7.2 Chromosomes

7.3 Cancer

7.4 DNA

7.5 Leukaemia

7.6 Life Shortening

7.7 Late Effects

7.8 Somatic-unspecified

7.9 Genetic

7.10 Others

7.11 Death

\section{APPLICATIONS}

8.1 Accidents, Emergencies

8. 2 Design Aspects

8.3 Occupational Exposure

8.4 Operational Health Physics

8.5 Legal Aspects

8.6 Medical-unspecified

8.6.1 Medical-Dental

8.6.2 Medical-Diagnostic

8.6.3 Medical-Therapeutic

8.6.4 Medical-Pharmaceutical

8.7 Public/Industrial Relations

8. 8 Risk/Benefit

8.9 Industrial Radiography

8.10 Fuel Reprocessing

8.11 Others 
8.12 Power Reactors

8.13 Decontamination

8.14 Cost/Benefit

8.15 Research Reactors

8.16 Radiation Protection Standards

ORGAN FUNCTIONS

9.1 Excretion

9.2 Epidemiological Aspects

9.3 Ingestion

9.4 Inhalation

9.5 Metabolism

9.6 Reproduction

9.7 Others

\section{MISC ELLANEOUS}

10.1 Education and Training

10.2 Fluoroscopy

10.3 Lasers

10.4 Microwaves

10.5 Fusion

10.6 Others

10.7 Bibliographies

10.8 Progress Reports

10.9 Accelerators

10.10 Background Radiation

10.11 Patents

ISOTOPES etc.

Coded by standard chemical symbols

第 13 図 AHPA の分類項目とコード

\section{ABSTRACTS}

\section{Organs and tissues.}

THE DEPOSITION MODEL OF THE TASK GROUP ON L.UNG DYNAMICS: A COMPARISON WITH RECENT FXPERIMENTAL DATA

\begin{tabular}{|l|c|c|c|c|c|}
\hline \multicolumn{2}{|l|}{ Abstract Number } & \multicolumn{4}{|c|}{1158} \\
\hline Code & 3.8 & 4.11 & 4.7 & & \\
\hline
\end{tabular}

T.T. MERCER (Department of Radiation Biology and Biophysics, University of Rochester, Rochester, NY 14642) (llealth Physics Vol.29, No.5, Nov 1975, pp.673-680)

A comparison with recent experimental data reveals that the Task Croup deposition model adequately describes total deposition during nasal breathing. Measurcinents made on subjects during normal breathing. support the use of Pattle's (1961) enpirical equation to define deposition in the nasopharyngeal compartment, but some of the new data indicate that pressure drop across the nose may be a significant parameter in nasal deposition. Although a very limited amount of data on a single subject suggests that the Task Group's model may underestimate pulmonary deposition during nasal breathing, Lippmann's (1975) extensive results on regional deposition during mouth breathing make it appear that the molel generally overestimates pulmonary deposition at the expense of tracheobronchial deposition.

第 14 図 AHPA の文献記述（右端のコード欄が独創的である）

をしないですますことができるのである。そのような便 利な文献集が，原子力分野では最近数多く発行されてい る。二, 三の主題を代表させて, 文献集の利用法を例示 しょう。

1.「放射性廃棄物中のトリチウム」について

さきにもとりあげた「放射性廃棄物中のトリチウム」 について，関連する文献集をあげてみよう。

(9) Radioactive Waste Processing and Disposal; A Bibliography of Selected Literature, 1958, 123 p. (TID-3311)。Suppl. 1, 184 p. (1964)。Suppl. 2, 180 p. (1966)。Suppl. 3, 592 p. (1972)。Suppl. 4, 119 p. (1973)。Suppl. 5, 92 p. (1973)。Suppl. 6, 283 p. (1975)。

1975年の追補 6 では分類項目はたてず，単純な登録番 号順（NSA の抄録番号順）に文献を収録している。本 文の文献記述は, 書誌的事項のみで, 抄録もキーワード
も付されていない。しかし，電算機処理による主題索引 には，多面的なキーワードがアルファベット順に打ちだ されている。

本文の文献収録は NSA の抄録番号順なので, 頭から サーベィしても関連の文献はなかなか見出せないので， 索引によって tritium の項を検索すれば，NSA による よりも手軽に必要文献にたどりつくことができる。

(10) Monitoring, Control, and Disposal of Tritium; A Selected Bibliography, U.S. AEC, 1973, 103 p. (TID-3337)

上記（9）と同様，分類項目はたてず，単純な登録番号 (NSA の抄録番号順) 飞文献を収録している。収録文献 数は約 400 件で，年代は 1967 1972 年である。本文の 文献記述は，書誌的事項のあとに特別なキーワードが付 されている。本文・索引とも，電算機処理によって打ち だされている。 
上記 (9) とは逆に，索引から Radioactive Waste を 検索して，必要な文献にたどりつくことができる。

(11) Indexed Bibliography on Tritium; its Sources and Projections, Behavior, Measurement and Monitoring Techniques, Health Physics Aspects, and Waste Management, by M.N. Dixon, et al., 1975, vp. (ORNL-5057)。

収録文献数 1291 件に達するトリチウムに関する文献 集で，比較的大規模なるのである。とくに環境問題，保 健物理的立場から見たトリチウムの文献といらことで は，扔そらく現在のところ世界1の水準であろう。

分類項目は，つぎの 11 項目に分れている。

1. Sources and Projections, 2. Operating Exderience, 3. Handling Procedures, 4. Measurement and Monitoring Techniques, 5. Environm ental Behavior, 6. Biological Behavior, 7. Healtt Physics Aspects, 8. Waste Management, 9. Resuh of Environmental Monitoring, 10. Non-Compliancle and Accident Reports, 11. Responses to Environmental Impacts Questions.

各項目は，(1)文献記述（書誌的事項と抄録），(2)キワード索引, (3)著者索引, (4)タイトル KWIC 索引から 成っている。

放射性廃棄物中の問題であれば，さしずめ第 8 項から 参照していけばよいであろう。この場合ならば，第 8 項 の頭から見ていっても，必要な文献にすぐたどりつけ る。もちろん，第8項のキーワードからあたっていって るよいし，また，ある考兄られらる文献のタイトルを予 想して，KWIC 索引にあたってもよい。このほか，文 献のタイトルだけはわかっているが，伍かのとは何も わからないなと゚という場合にも KWIC 索引を使って, 目的の文献にたどりつくことができる。本文献集は，こ のよう约多面的に利用できるきわめて便利なトゥール である。

\section{2.「原子力施設の閉鎖」について}

最近，原子力分野で問題になっていて，「原子力工業」 誌（1976年 4 月）でも特集としてとりあげられた原子力 施設の閉鎖に関する文献集も発行されている。閉鎖 (decommissioning) または解体 (dismantling) 飞関す る文献は，前出(9)の放射性廃棄物に関する文献集にる若 干収録されているが，より完全にまとめられた文献集と してはつぎの 2 点がある。

(12) Decommissioning of Nuclear Facilities; A Bibliography, Prep. for Div. of Waste Management and Transportation, 1974, 11 p. (TID-3344)
収録文献数は約 80 件で，小規模であるが，実によく まとまった文献集である。本文の文献の記述は, NSA か らの転載である。索引はないが，この程度の規模ならば むしろ索引は不要で, それよりも早く編さんして発行し てもらった汪らがよい。

本文献集は，原子力施設の閉鎖について全般的な関心 をもって調查しょうとする人にとっては，まさに適切な 資料である。この問題について NSA で調査すると, 数 年分で丸半日はかかってしまう。このような場合，その 調查の当初，適時にこの文献集を図書館側から提供でき れば，NSA による文献調查時間を，活とんど0にして 解消させることができる。実は，この文献集は，入荷し てきたその日に（現物はマイクロフィッシュ形態で，1 回約 400 件の単位で入荷する)，この問題について質問 を受け，ただちに提供して好評を博した，筆者にとって 深い印象のある文献集である。

(13) Decontamination and Decommissioning Eof Nuclear Facilities; A Literature Search, 1975, 155 p. (BNWL-1917)

1944 1974年の文献 429 件を収録し，年代順に配列さ れている。文献の記述は，書誌的事項のあと，抄録がつ いている。また，索引も完備している。

（12）よりる細かい問題に関する文献をも網らして招 り，現場の実務にも役立つ文献集である。原研所内で は，数部以上複製された。

上述したような文献集の発行状況は，どの分野(問題) にあ等しくあてはまるわけではない。ある分野では，上 記のように色濃く塗られているのにたいして(つまり， かなり網ら的な文献集が発行されている)，べつの分野 ではまったく白紙であるのが現状である。

このような文献集発行の現状を知るには, 文献集の文 献集 (3 次資料，または書誌の書誌ともいう）が定期的 に発行されなければならない。

(14) Bibliographies of Interest to the Atomic Energy Programs; 1962 1966, 1968 (TID-3350)

これは，原子力分野の文献集約 2000 件を収録する文 献集である。本文の配列は, 文献集の発行機関の A B C 順である。記述は書誌的事項のあと，抄録がつき，文献 集の性格, 目的, 主題・年代範囲, 収録件数等が記載さ れている。巻末には詳細な主題索引，レポート番号索引 等がついている。これにより，1966年をでの原子力分野 の文献集が概観できる。なお，これ以降の文献集につい ては NSA からあたる以外にはない。

ただしこのような文献集の文献集といったような資 料については, 研究者によく知ってもらいたいと願って 
ここに書いているわけではない。このよらな資料の知識 は, 主として図書館員が持たなければならないものであ る。

\section{VIII 文献調查の実際}

上述したような抄録・索引誌および文献集の利用は, たしかに文献調査の基本であり，また端緒である。しか し, 文献の利用者である研究者・技術者は, なにも 2 次 資料を使わないでも，なんらかの手段で，自分に関係す る資料が直接入手できれば，ただちに読むことができる から，それが 1 番よいのである。

長年同じ研究に従事している研究者ならば, 経験的に 自分に関係する文献が大体どらいう資料涀われるかを 知っているので，直接原著雑誌にあたっていけばよいの である。そして，研究の当初から積算してみると，それ ぞれの研究者はかなりな量の文献情報を蓄積しているむ ので, 自分の分野について大よその全世界の傾向, 水準 をつかんでいるのが普通である。このように，直接 1 次 資料にあたるのも文献調查である。

このような文献調査をして図書館から帰ってきた研究 者, つまり同僚から自分に関係する文献が図書館の新着 資料のなかにあったことを教えてもららのも文献調査で ある。

また，新しい研究に着手した場合，まず読むべき文献 を上司から指示されるのも文献調查である。すべてこう いったことは, 研究者側はよくわかっているが, 図書館 員のほうはよくわかっていないらしい。一般に図書館側 は, 文献調查はイコール2 次資料之考克, われらが整備 した 2 次資料をあまり使ってくれないとなげくものであ る。そうではなくて，2 次資料はあくまでも不可欠な基 本資料なのである。それはともかくとして，一方，研究 者側があまりよくわかっていないと思われる事項がもう 1つあるように思われる。それは, 図書館員をもっと利 用することである。

そもそも図書館は，過去の文献を蓄積する場であると 同時に，新しい文献が入荷する場である。図書館システ ムが確亡している機関ならば, 部分的には直接研究者の ところへ必要な資料は入ってもくるが，その機関が必要 とする全体としての資料は，まず第 1 亿図書館に入って くる。これらの資料にたいして, 研究者はその知識内容 について責任があり，図書館員はその媒体としての資料 に責任がある。したがって，図書館員はその資料の流 通, 提供にかかわるすべてについて責任があり, それら の知識を身につけていなければならない。このよらな図 書館員であるはずだから，研究者は図書館員を十分に利
用できるわけである。

\section{1. ふたたび「トリチウム」について}

保健物理分野の研究者のテーマがトリチウムに関する ことであれば，図書館員はまず最初に(11)の文献集を提 供するはずである。自機関の図書館にその文献集 (ORNL 5057) を所蔵しているならば，その図書館員には提 供できるはずである。なぜならば，文献集は，便覧類や 辞書と同じく, 図書館員の守備範囲にはいる資料形式だ からである。しかも, トリチウムの問題は新聞の解説記 事にとさどきでる重要問題だから, 四書館員はその研究 内容をでは知らなくとも，それに関する文献集がいかに 重要であるかはわかるはずであるし，またわからなけれ ばならない。

もし自機関にその文献集を所蔵していながら，図書館 員がそれを出せなかったら，その図書館員を教育してや る一端の責任は研究者の側にもある。とはいっても, そ らむずかしいことではない。研究者は，自分でその文献 集を捜し出してきて利用したあと，それがいかに有用で あったかを，そして今後このような文献集が出た場合に は知らせてくれるように図書館員にいっておけばよいの である。個々の文献になると, 図書館員のほうから1件 1 件知らせるわけにはなかなかいかないが，このような まとまった文献集となると，また話はべつになる。司書 の資格のある普通の図書館員ならば, 次回からは出すこ とができるようになるであろう。

もら少し訓練された図書館員ならば，(11)の文献集の ほかに, Tritium Symposium, 1973 の会議議事録や 23rd Remote System Technology Conference $の$ Tritium Session, 1975 を提供してくれるかもしれない。また， 新着雑誌 Nuclear Technology や Annals of Nuclear Energy のなかにトリチウムに関する論文がのってい ることを指示してくれることもあろう。

研究者の文献調查が 2 次資料の調査だけで終らないの と同じように，図書館員のほうも新着資料目録の発行た けでよいのではなく, 重点的な 1 次資料を直接提供して よいのである。研究者は, そのように図書館員を教育し て利用すれば，また自分の利益にもつながることとな る。

\section{2. ふたたび「原子力施設の閉鎖」について}

上記の例は，原研図書館に打いて行なわれている，考 えられらる文献提供の 1 つのパターンであるが，もら 1 つ具体例をあげてみよう。

最近，「原子力施設の閉鎖」についての質問があっ た。といらよりはまず「IAEA-179 といらレポートは ないか?」といら電話が最初にあった。研究者はほとん 
どすべて，研究テーマ名ではなく，資料名で図書館に聞 いてくるものである。これは，研究者が図書館員を信用 していないからではなく（場合によってはそれもある が)，ある資料が必要だからという切実な要求からだけ で図書館に聞いてくるのである。それはそれでよいの で，図書館側はその所蔵有無の質問を最る大切にしてい ることは事実である。

だから，所蔵有無の質問には，資料があってもなくて も，図書館員はその質問の背後にある研究テーマにたい して，文献を提供できるよう準備している。つまり，所 蔵の質問は, 研究テーマに関する文献調查（図書館のレ ファレンス活動）のきっかけだと解している。

「IAEA-179 の所藏有無」の質問にたいして, 実際に は，「そのレポートはまだ入荷して和りませんが,ぞうい らテーマに関するレポートでしょらか?」と問い返して いる。すると, decommissioning であるという返事が かえってきた。そこで直ちに「原子力施設の閉鎖」なら ば, 最近入荷した会議資料 (CONF-750827 Decontamination and Decommissioning of Nuclear Facilities, 1975, 521 p.) ならば所蔵しているむねを伝えた。事実, その研究者はすぐ来館して, 資料を確認のら充, 複写の 依頼をして縞られた。

この応待とその結果は，一見するところ代替物を与兄 たように見えるが，決してそらではない。現実問題とし て，ごまかしでもなければ，代替物の提供でもなく，所 蔵の質問を一言によって，ただちにその背後にある研究 テーマの質問にきりかえさせて，それに答える図書館の レファレンスを行なったことになる。

このような結果からすれば, 研究者のほうでも, もう すこし上手質問してもらいたいよらに思う。まず，最 初に「IAEA-179 は所藏しているか?」といら質問は結 構であるが，もしそれにたいして「所蔵なし」といら答 えが返ってきたならば，その資料を必要とする主題の範 囲または性格いかんで，この場合ならば，「それでは原 子炉の閉鎖についてなにかまとまった文献はないか?」 というように問い合せてみる方法もあるのではあるまい か。要するに, 研究者側からは, 自分の要望をあますと こなく，卒直に図書館員に質問すればよいのである。図 書館側もとのことを望んでいる。

図書館員の活らからす机ば，いつも上記 2 例の上らに うまくいくわけでもないことも事実であるが，大ていの 場合, 上記の 2 例をモデルとして，いくらでも答光てい けることも事実である。トリチウムのかわりに，ヨウ素 でもクリプトンでも何でもこなしていく資料面での知識 を蓄積しているのが図書館員である。
研究者は, 図書館が収集している1 次資料や 2 次資料 を利用すると同時に，上記のような資料の知識のある図 書館員をるっと利用すべきである。現在，たと学そのよ らな眓書館員がいなくても, 近い将来, そのような図書 館員が養成され, その図書館活動がさらにシステムとし て発展していかなければならない。この責任は, 単に図 書館側だけにあるのではなく, 研究者側にもあり, 研究 者の卒直な意見・要望が出されて，はじめて 1 歩 1 歩前 進するものである。

\section{IX おわりに}

私事にわたるが，小生原研図書館に勤務して以来 20 年 を過ぎるが, その当初のころ, 廃棄物の責任者として入 所してこられた杉本仙市氏 (現在, 東京理科大学) から ご挨拶を受けた。その当時をかえりみると，まだほんの 若僧の小生にたいして, 廃棄物を担当させられることに なりまして，文献についてはなにるわからないのでよろ しく、といらような拉言葉だったと記憶している。それ にたいして小生は，いまから思光ば無礼にも言葉尻をと らえて、「なにもわからなくて，よく原研へこられまて たね。そんなことがあるんですか?」とたしか申しあげ た。すると杉本氏はすこしも顔色をかえずに，「これま でわたしは○○会社の実験室に和りまして, 今度はじめ て放射性のほうに移りましたので，本当になにも知らな いのです」と絽返しいわれる。原研の研究者は，みな湯 川さんだと思っていた小生にとって，これはすこし意外 であったが，ぞうやら本当らしい。そこで，ではいった いぞらすれば沶手伝いできるのかを聞いてみると， Radioactive Waste といら言葉のはいっている文献を見 受けたら教えてほしいといらようにいわれた。それから 新着レポートをよく見てみると，そのようなレポートが ときどきある。そこで打電話をいれると，大ていはその 日のらちに来館された。そして文献を間にして，小生の ほらから聞けば，廃亲物のことについて，それには固体 と液体と気体があるといった初歩的な事柄から，それら の処理・処分方法なぞ，理工学的知識にとぼしい小生に もわかりやすく教えていただいたものである。

現在，アースク・レファレンスと命名して，筆者らを 中心に推進している情報資料の積極的提供活動の端緒と なったのが上記の事情である。ちなみに，アースク・レ ファレンスとは, 旧来の図書館のレファレンスが利用者 からの質問を受けて始まる受動的なるのであるのにたい して，もちろんそれも受付けるが，さらに 1 歩進んで, 文献を媒介として図書館員のほうから問いかけていく (つまり，アースクする) 積極的なレファレンス活動で 
ある。これについては, 図書館の立場からすでにのべて いるので，ここではこれ以上ふれないが，アースク・レ ファレンスは旧来のレファレンスでは得られなかった新 着資料の即時的入手，隣接分野の新傾向の情報といった ようなことが有機的に得られるシステムに段階的に発展 しつつある。

思觉ば，杉本氏から教兄られてから10数年になるが， その間を通じて，できるかぎりその教えを実行してきた つもりである。その後，もちろん数多くの研究者からい ろいろのことを教えていただいた。その氏名をあげてい くと，杉本氏をはじめとして，保健物理部門の研究者が 最も多きに達する。小生年齢 40 数年にしていまだ若い が，多小なりとも蓄積した文献情報の経験知識を，今度 は少しずつでも還元していかなければならないと考えて いた矢先に，本稿の依頼があったので，喜んで招受けし た次第である。
いささか主観的な「あとがき」となってしまったが， 本文の執筆の背景はそらいう点にある。な扔，本文につ いては，2 次資料の解説が主となっているので，いかに 図示しても，現物を見るまで隔靴搵痒の思いをされるこ とであろう。例示した資料はすべて原研図書館が所蔵し ているので, 関心のある方々の来館を期待している。

最後に，本稿の執筆にあたってその機会を与えていた だき, ご教示を受けた原研保健物理部の和達嘉樹, 藤田 稔, 赤石準の各氏にたいして（とくに赤石氏からは貴重 な私信をいただいた)，厚く感謝の言葉をのべる。

\section{参 考 文 献}

1）大森栄一; 国際原子力情報システムの概要, 原子 力産業新聞，第 812 号（1976年 2 月 12 日）

2）赤石 準；私信（1976年 4 月）

\section{日本保健物理学会 Back Number 一覧表}

1. 保健物理のための生物学

B 5 判 9 裁, 396 頁, 定価 1500 円, 送料 350 円

2. 円卓討議記録

「保健物理の観点からホット・パーティクル問題を考学る」昭和 50 年 12 月 19 日, 神田・学士会館

B 5 判, 43 頁, 定価 500 円, 送料 200 円

3. 放射線管理計測法

4. 第 11 回研究発表会予稿集

5. 現状に扣ける放射線管理測定技術

6. 円卓討議記録

「保健物理に括ける Cost-Benefit 解析の適用」

7. 放射性ヨウ素取扱いの保健物理

申込方法：ハガキまたは現金書留で

申 込 先：(財) 日本学会事務センター 日本保健物理学会係

113 文京区弥生 2-4-16 03-815-1903
B 5 判, 20 頁，定価 400 円（送料込）

B 5 判, 54 頁, 定価 600 円 (送料込)
B 5 判, 84 頁, 定価 1000 円, 送料 200 円

B 5 判, 212 頁, 定価 2000 円 (送料込)

B 5 判， 127 頁，定価 非会員 2000 円，会員 1500 円，送料 200 円 